\title{
Professionalism Concept of Work Ethic in Islamic Perspective
}

\author{
Mohammad Ghozali ${ }^{1}$, Syamsuri $^{2}$, Daniar $^{3}$, Agung Eko Purwana ${ }^{4}$, Lutfy Ditya Cahyanti ${ }^{5}$ \\ mohammadghozali@unida.gontor.ac.id,
}

University of Darussalam Gontor, Raya Siman Street, KM 6 Ponorogo, 634711,2,3,4,5

\begin{abstract}
A Human being is the most crucial asset for management. People need to be provided with Islamic personality that will guide and help people to act and to behave as a Muslim who professional in work, furthermore, every member of the organization must have high knowledge with sufficient skills to carry out their duties and responsibilities. Professionalism is the level of competence, accountability, and responsibility that should be supported by such a professional, also associated with loyalty and commitment and positive behaviour leading to the achievement of organizational goals and, it is an obligation and the purpose of service. This study aims to illustrate that Islamic teachings provide the perfect conceptual foundation of the underlying problem of actively working activism, Faith as a Professional Policy, which further calls for an expression of activism that requires a proportionate contribution to achieving Higher Degree. The methodology of this study is used in this discussion based on the qualitative study pattern. This study conclude that the characteristics of the soul that must be possessed by someone in carrying out the burden of responsibility and elements of the element that must be met as a professional in Islam, ability, Himmah al-Amal (spirit of work), 'Awfu bi al 'Uqud (Holding the Covenant) and Ansarullah. This characteristic is necessary to build a knowledge management system in a work ethic.
\end{abstract}

Keywords: Professionalism, work, Islam, Knowledge Management

\section{Introduction}

A professional is when an individual was advanced in the field of work where he gained income from there. A job is a task that calls like obligations, undertaken by individuals when necessary, such as secretarial work which included typing, summarising, auditing, welcomed guests and others who have a sense of Job. It means that based on the fundamental job skills possessed by each offender workers cloning.

Several indicators and criteria support proficiency, are as follows; academic qualifications or educational background, qualified skills and experience in the field, and practised in the field

In Islam, to convey the same professionalism endeavoured resourcefully; highly recommended in Islam. Work happenings are unequal in terms of use obligation (duty, task), position (position), and occupation (occupation). In various institutions. Sometimes used as the same vocabulary, and sometimes also used to indicate different levels of the profession. Such as with the term Muslim professionalism [1]

In this life, we often hear the term professional. For example in the world of sports, players who have started on a salary or get paid work in the grades of the professional players, as well as in the world of work. Those who work diligently, neatly and get the award, for example in the form of salary referred to the professional worker. This study aims to illustrate 
that Islamic teachings provide the perfect conceptual foundation of the underlying problem of actively working activism, Faith as a Professional Policy, which further calls for an expression of activism that requires a proportionate contribution to achieving Higher Degree.

\section{Materials and Methods}

In terms of purpose, the methodology is a system that includes the methods and principles used in activities, disciplines and so on [2]. Even more importantly, it will act as one of the indicators in determining the validity and strength of the Concept and the findings of the study conducted. Hence, this study based on the qualitative study pattern [3].

Researchers used library research methods to collect as much data directly or indirectly with the subjects studied. It involves the process of referring to books, encyclopedias, dissertations, theses, journal articles, published or unpublished printed papers, official guides or reports from BMI institutions and so forth about the subject of this study.

\section{Result and Discussion}

Islam is a system of doctrine which gives a general concept covering all aspects of life. Arrangements against the guidance of the various aspects in Islam is unique so that it has three pillars, Namely;

\section{Moral Basis of Faith}

It means that belief in the existence of God, angels, Al-Kitab, apostles day and Qadaqadar hereafter. A believer will be activities as worship. In the context of prayer, all the work is not intended to satisfy employers, consumers, or the praise of men. Worship is the mobilisation of the whole effort to achieve the highest position before God. He will come first. Rule of God comes first. Dedication, and sacrifice to God, the motivation of faith. Makes the job feel meaning full. Work into a pleasant land because it is the best work he can do. The work is seen as the work of saving for the future of the eternal hereafter. This would build sincerity heart, meaningful, and oriented to seek permission to worship God. Everything around the underlying principles of faith needs to be done. Stems rather than fostering the concepts, views, attitudes, thinking styles, so determining what type of action within the organisation. Those who believe will carry out any form of trust that has been responsible for him sincerely for Allah most humble and continues to do our best because God is sharper than human supervision. Here a sense of faith among the workers will leave a positive impact on the organization and the next generation.

\section{Islam as an operational expression.}

Someone who works to uphold Islamic law in all matters Mahdoh or Ghoirumahdoh. Islamic teachings are broad, deep, and perfect enough to give specific and clear direction, and by human nature are, $100 \%$ are related to morality. So, nothing can be separated from the teachings of Islam. However, Islam does not teach the separation of religious affairs and the affairs of life as there is no relationship between the economy of religion, of politics with religion, between religion and society with many more people confused by the Orientalists. 


\section{Ihsan as the quality}

Ihsan is closely related to professionals. As with any charity, professional work demands are the result or the quality of the work already done. Ihsan is defined as, "You worship Allah as if to see him, if you cannot see Him, surely He sees you". In practical work, we work as if we give to the 'king of kings' that so perfectly the job.

Ihsan covers three main:

1. Ikhlas \} al-niyah. (sincere Intention)

2. Itqa $n$ al-'amal; (Neat in work)

3. Jawdat al-ada'; (done thoroughly and complete the job retention)

\section{Examples of Inspiration and Professional Work in Islam}

1. Working with Science and Understanding

2. Working with Discipline

3. Working with the Planning:

4. Working with a Clear Target

5. Working in the Early Morning

6. Working with the Research and recording

7. Working with the Use of Technology and Methodology:

\section{The Characteristics of Professionalism in Islam}

"Legal origin of action is bound by law shar'ie so that any behaviour that exists in every human being, everything is tied directly to the rules that have been revealed by Allah [4].

The following will explain some measure of professional;

a. Kafa'ah (able)

Kafa'ah is the expertise and skills in the areas of work performed. Kafa'ah or the expertise and skills acquired through education, training, and experience. Islam warned that contain people who are not experts or people who are not exactly be classified as those who violate the mandate and treason against Allah, His Messenger and the Believers.

"Those who appoint a leader of the congregation, in case he knows that in the group that there is a better person, then he has betrayed Allah, His Messenger and the believers." (Narrated by al-Hakim)

"If a business (jobs) submitted to the people who are not experts, so watch the destruction." (Narrated by Al-Bukhari)

Therefore, Islam gave great attention to the many efforts to improve expertise and skills. To reach that all required an understanding of the science as Islam. Studying a form of benevolent actions, Islam praised the academic and enterprising study. In fact, in reality, there are three kinds of scientific truth [5] namely

1. Truth I'tiqadi (Imani)

2. GuessSyar'i

3. Truth Waqi'i

b. Himmat al-Jamal (working spirit)

Work ethics is emerging because of the existence of work motivation. If motivation didn't stop and sustainable, what people would see is high work ethics. One would be said having a professional attitude if he is always in high spirits and meaningful in running the job he appointed to. Islam is highly encouraging every Muslim to work hard, and an effuse a lot of energy and ability in running many task and responsibility. 
The first impulse given toward a Muslim when he is working is that Islam has viewed all job activity as tight toward Islamic Syariah law as the form of Ibadah toward Allah SWT. It is in accord with first Ihsan meaning as explained before.

Therefore Allah and His prophet highly like every diligent and hardworking Muslim or those who have the high working ethos and praying blessed for him. Even when there is no task at hand, a Muslim is recommended to do something although it is only to help his other brother. By doing this, his skills or ability will not be reduced or gone.

It is told from Abu Dar r.a he said "I have once asked Rasulullah SAW, 'Rasulullah! What is the main deed? Rasulullah says Have faith for Allah and fight in His way. I ask again, What is the main type of servant? Rasulullah SAW said, 'The best servant according to his owner and the one with the highest price. I ask again, "What if I don't go to work? Rasulullah SAW says, You might help those who work, or you should work for those who didn't have a job. I ask, Rasulullah! What would you say if I am not able to do part of my deed? Rasulullah SAW says "Then you should stop being mean toward others because it is your shadaqah for yourself." (HR. Bukhari)

"Allah SWT likes to see His servant is an effort to look for halal fortune (HR. Ad-Dailami)

Concerning hard work, we might compare with Japanese society working culture with its Shinto and kaizen and give birth to bushido and Makoto attitude which is meant to be genuinely devoted toward the emperor. It is worth thinking, is it worth if we work for Allah in rush demeanour?

c. Awfu bi al-' $u q u>d$ (held his promises)

Any job will always contain interacting with other people, as a partner or a consumer to be dealing with. In business reality, it is always accompanied by a commitment to gain benefit. One way to maintain this commitment is by making business Aqad, an agreement or cooperation, a treaty. For this concern, it usually is presenting witnesses to strengthened and witness those momentous events.

A Muslim is expected to fulfil every syar'I demand in Aqad, not only as a profitable professional act in business view. Allah say;

Fulfil the Covenant of Allah when ye have entered into it, break not your oaths after you

have confirmed them; indeed ye have made Allah you're for Allah knoweth all that ye do.

(An-Nahl 16;91)

O you that believe! Betray not the trust of Allah and the Messenger, nor misappropriate knowingly things entrusted to you. (al-Anfaal 8; 27)

In many things, fulfilling an agreement will bring friendship and spreading venture. Thus, behaviour in keeping promises is viewed as a merit investment and reflection of Islamic personality (Syakhsiyah al-Isla>mi). This act is a professional act and Muslim clergy (ulu al$b a>b$ ) highly educated and not uneducated. Allah say;

19. is the one who doth know that that which hath been revealed unto Thee from Thy Lord is the truth, like one who is blind? It is those who are endued with understanding that receives admonition;-20. Those who fulfil the Covenant of Allah and fail not In their plighted Word;

21. those who join together those things which Allah hath commanded to be joined, hold their Lord In awe and fear the terrible reckoning; (Al-Ra'd 13; 19-21)

Act in disrupting Aqad or agreement will bring damage for all human related. It is reflecting the unprofessional person. Because the essence is that they have breached Allah provision as in the above verse. Allah say and clarify in this matter 
25. But those who break the Covenant of Allah, after having plighted their word to it, and cut asunder those things which Allah has commanded to be joined, and work mischief In the land;- on them is the curse; for them is the terrible home! (al-Ra'd 13;25)

d. Ansarullah (Willing to help)

A professional act for a Muslim is reflected in his heart or Islamic personality (Syakhsiyah al-Islami) as Dhohir (reality) and felt as pious deed in consequences of faith in which felt by people surrounding him. As if he is the extension of Allah's mercy for humankind through his knowledge to help among people. With this knowledge, a professional attitude is born and being the exercise for the good of humankind. Knowledge without deed is like a tree without fruit. In the end, he will become a great tree with its root (faith) has perforating earth and its branches will protuberant toward the sky with its fruit (deed) would be able to be enjoyed by anyone in need.

Helping people is identical to helping Allah religion. The more he became the helper among people using excellent and appropriate way; it will strengthen his position among the community Allah has said;

7. O ye who believe! If ye will aid (the cause of) Allah, He will assist you, and plant your feet firmly. (Muhammad 47; 7)

90. Allah commands justice, the doing of good, and Liberality kith and kin, and He forbids all shameful deeds, and injustice and rebellion: He you, that ye may receive admonition.

(An-Nahl 16; 90)

"Anyone who can give benefit toward his brother or sister, where he should do" (HR. Muslim)

e. Amanah

Amanah has the same root as Amin (credible). One with the title Al-Amin means a person is feeling safe if they give task or Amanah toward him because he will take responsibility for the task appointed to him. Using Amanah, people will feel safe from betrayal, cheating, lying and breaking promises. Rasulullah has described people who are always breaking Amanah as a hypocrite.

"There is three sign of a hypocrite if speaking tell lies if promising he breaks it, and if giving trust, he betrayed" (HR. Ahmad)

Amanah has been shown by the Prophet's personality when he was appointed to be the firm manager by Khodijah. Honesty with artfulness has given rise to blessing in this venture he runs.

f. Himmat al- 'amal (working spirit)

Work ethics is emerging because of the existence of work motivation. If motivation didn't stop and sustainable, what people would see is high work ethics. Islam has always taught us to work hard, and effuse a lot of our energy and ability in dealing with our task which made Ibadah motivation as a significant encouragement other than rewarding motivation and punishment motivation also material gain.

One will be said having a professional attitude if he is always in high spirit and meaningful in running the job he appointed to. Islam is highly encouraging every Muslim to work hard, and an effuse lot of energy and ability in running many task and responsibility.

The initial impulse given toward a Muslim when he is working is that Islam has viewed all job activity as tight toward Islamic Syariah law as the form of Ibadah toward Allah SWT. It is in accord with first Ihsan meaning as explained before.

Therefore Allah and His prophet highly like every diligent and hardworking Muslim or those who have a high working ethos and praying blessed for him. Even when there is no task 
at hand, a Muslim is recommended to do something although it is only to help his other brother. By doing this, his skills or ability will not be reduced or gone.

It is told from Abu Dar r.a he said "I have once asked Rasulullah SAW, 'Rasulullah! What is the main deed? Rasulullah says Have faith for Allah and fight in His way. I ask again, What is the main type of servant? Rasulullah SAW said, 'The best servant according to his owner and the one with the highest price. I ask again, "What if I don't go to work? Rasulullah SAW says, You might help those who work, or you should work for those who didn't have a job. I ask, Rasulullah! What would you say if I am not able to do part of my deed? Rasulullah SAW says 'Then you should stop being mean toward others because it is your shadaqah for yourself." (HR. Bukhari)

"Allah SWT likes to see His servant is an effort to look for halal fortune (HR. Ad-Dailami)

Concerning hard work, we might compare with Japanese society working culture with its Shinto and kaizen and give birth to bushido and Makoto attitude which is meant to be genuinely devoted toward the emperor. It is worth thinking, is it worth if we work for Allah in rush demeanour?

g. Awfu bi al-'Uqud (held his promises)

Any job will always contain interacting with other people, as a partner or a consumer to be dealing with. In business reality, it is always accompanied by a commitment to gain benefit. One way to maintain this commitment is by making business Aqad, an agreement or cooperation, a treaty. For this concern, it usually is presenting witnesses to strengthened and witness those momentous events.

A Muslim is expected to fulfil every syar'I demand in Aqad, not only as a profitable professional act in business view. Allah say;

91. fulfil the Covenant of Allah when ye have entered into it, break not your oaths after ye have confirmed them; indeed ye have made Allah you're for Allah knoweth all that ye do. (An-Nahl 16;91)

27. O ye that believes! Betray not the trust of Allah and the Messenger, nor misappropriate knowingly things entrusted to you. (al-anfaal 8; 27)

In many things, fulfilling an agreement will bring friendship and spreading venture. Thus, behaviour in keeping promises is viewed as a merit investment and reflection of Islamic personality (Syakhsiyah al-Isla>mi). This act is a professional act and Muslim clergy (ulu al$b a>b$ ) highly educated and not uneducated.

Allah say;

19. is the one who doth know that that which hath been revealed unto Thee from Thy Lord is the truth, like one who is blind? It is those who are endued with understanding that receives admonition;-20. Those who fulfil the Covenant of Allah and fail not In their plighted Word;

21. those who join together those things which Allah hath commanded to be joined, hold their Lord In awe and fear the terrible reckoning; (Al-Ra'd 13; 19-21)

Act in disrupting Aqad or agreement will bring damage for all human related. It is reflecting the unprofessional person. Because the essence is that they have breached Allah provision as in the above verse. Allah say and clarify in this matter

25. But those who break the Covenant of Allah, after having plighted their word to it, and cut asunder those things which Allah has commanded to be joined, and work mischief In the land;- on them is the curse; for them is the terrible home! (al-Ra'd 13;25) 


\section{Conclusion}

This study conclude that the characteristics of the soul that must be possessed by someone in carrying out the burden of responsibility and elements of the element that must be met as a professional in Islam, ability, Himmah al-amal (spirit of work), 'Awfu bi al 'Uqud (Holding the Covenant) and Ansarullah. This characteristic is necessary to build a knowledge management system in a work ethic.

\section{References}

[1] P. Yadi, Psikologi Kepribadian. Bandung: Refika Aditama, 2007.

[2] H. Noresah, Kamus Dewan., 3rd ed. Kuala Lumpur: Dewan Bahasa dan Pustaka, 2000.

[3] N. Muhajir, Metode Penelitian Kualitatif, 4th ed. Yogyakarta: Rake Sarasin, 2000.

[4] M. K. Widjajakusuma and M. I. Yusanto, Menggagas Bisnis Islami. Jakarta: Gema Insani Press, 2002.

[5] M. I. Yusanto, Manajemen Styrategis: Perspektif Syariah. Jakarta: Penerbit Salemba, 2003. 